\title{
PERILAKU HIGIENE PRIBADI TERHADAP KECACINGAN PADA MURID SDN MUARA PAGATAN UJUNG, KECAMATAN KUSAN HILIR KABUPATEN TANAH BUMBU
}

\author{
Budi Hairani ${ }^{1 *}$, Annida$^{1}$, Erly Hariyati ${ }^{1}$, Dicky Andiarsa$^{1}$, Juhairiyah $^{1}$ \\ ${ }^{1}$ Balai Penelitian dan Pengembangan Kesehatan Tanah Bumbu, \\ Jl. Loka Litbang Kawasan Perkantoran Pemda, Batulicin, 72211, Kabupaten Tanah Bumbu, Indonesia
}

\begin{abstract}
Helminth transmission in primary school age children can occur due to poor personal hygiene behavior. One of the keys to successful control of helminthiasis is to improve the personal hygiene behavior of the community, especially in the most vulnerable groups primary school age children. This study aims to determine the prevalence of helminthiasis in students of Muara Pagatan Ujung Elementary School and to identify children's behavioral factors in maintaining personal hygiene behavior that are thought to be at risk of helminth infection. A cross-sectional study was carried out at Muara Pagatan Ujung Elementary School, Kusan Hilir District, Tanah Bumbu Regency in December 2016. Data collected in the form of fecal examination results and the results of interviews with students. The study result known that the prevalence of helminthiasis is $13 \%$. Interview results of several factors of student hygiene behavior toward helminthiasis that is still quite high, namely not using footwear every time they leave the house (54\%), not washing their hands and feet after playing on the ground (47\%) and not washing their hands with soap before eating (50\%). It is necessary to educate students intensively about the importance of maintaining personal hygiene behavior, especially the habit of washing hands and feet accompanied by the provision of hygiene support facilities in schools such as a place to wash hands with soap and regulations that require students to always wear footwear.
\end{abstract}

Keywords: Helminthiasis, prevalence, personal hygiene behavior.

\section{PERSONAL HYGIENE BEHAVIOR TOWARDS HELMINTHIASIS IN STUDENTS OF MUARA PAGATAN UJUNG ELEMENTARY SCHOOL, KUSAN HILIR SUB-DISTRICT, TANAH BUMBU REGENCY}

\begin{abstract}
Abstrak
Penularan kecacingan pada anak usia sekolah dasar dapat terjadi dikarenakan perilaku higiene pribadi yang kurang baik. Salah satu kunci keberhasilan penanggulangan kecacingan adalah dengan memperbaiki perilaku higiene pribadi pada masyarakat terutama pada kelompok yang paling rentan tertular yaitu anak usia sekolah dasar. Penelitian ini bertujuan untuk mengetahui tingkat prevalensi kecacingan pada murid SDN Muara Pagatan Ujung serta mengidentifikasi faktor perilaku anak dalam menjaga kebersihan pribadi yang diduga berisiko terhadap penularan kecacingan. Penelitian dengan desain potong lintang dilakukan di SDN Muara Pagatan Ujung, Kecamatan Kusan Hilir Kabupaten Tanah Bumbu pada bulan Desember tahun 2016. Sampel merupakan total sampling dari seluruh populasi siswa SDN Muara Pagatan Ujung. Data yang dikumpulkan berupa hasil pemeriksaan feses dan hasil wawancara pada siswa. Diketahui prevalensi kecacingan sebesar 13\%. Hasil wawancara beberapa faktor perilaku higiene siswa terhadap kecacingan yang masih cukup tinggi yaitu tidak menggunakan alas kaki setiap keluar rumah (54\%), tidak mencuci tangan dan kaki setelah bermain di tanah $(47 \%)$ dan tidak mencuci tangan pakai sabun sebelum makan $(50 \%)$. Perlu dilakukan edukasi pada siswa secara intensif mengenai pentingnya menjaga kebersihan pribadi terutama kebiasaan mencuci tangan dan kaki yang diiringi dengan pengadaan fasilitas pendukung
\end{abstract}


kebersihan di sekolah seperti tempat cuci tangan dengan sabun dan adanya peraturan yang mengharuskan siswa untuk selalu memakai alas kaki.

Kata kunci: Kecacingan, prevalensi, higiene pribadi.

Naskah masuk: 29 Agustus 2019; Review: 2 November 2019, Layak terbit: 8 April 2020

*Alamat korespondensi penulis pertama: e-mail: budihaira@gmail.com; Telp: 081258102006

\section{PENDAHULUAN}

Infeksi cacing merupakan penyakit yang terabaikan, sampai saat ini masih belum teratasi dengan baik terutama di daerah beriklim tropis dan pemukiman dengan kondisi sanitasi yang buruk. $^{1}$ Cacingan dapat mengakibatkan menurunnya kondisi kesehatan, gizi, kecerdasan dan produktivitas penderitanya sehingga secara ekonomi banyak menyebabkan kerugian, karena menyebabkan kehilangan karbohidrat dan protein serta kehilangan darah, sehingga menurunkan kualitas sumber daya manusia. $^{2}$

Lebih dari 1,5 miliar orang atau $24 \%$ dari populasi dunia terinfeksi cacing yang ditularkan melalui tanah. Infeksi tersebar luas di daerah tropis dan subtropis. Lebih dari 267 juta anak usia prasekolah dan lebih dari 568 juta anak usia sekolah berada di daerah terjadinya penularan cacing secara intensif. Anak-anak tersebut membutuhkan pengobatan dan pencegahan dari penularan cacingan. ${ }^{3}$ Prevalensi cacingan di Indonesia pada umumnya masih sangat tinggi, terutama pada golongan penduduk yang kurang mampu dengan sanitasi yang buruk. Prevalensi cacingan bervariasi antara 2,5\%-62. Beberapa hasil survei maupun penelitian di Kabupaten Tanah Bumbu menunjukkan prevalensi kecacingan masih cukup tinggi, pada tahun 2016 di salah satu sekolah pernah mencapai lebih dari $80 \%{ }^{4} \quad$ Upaya penanggulangan kecacingan sudah dilaksanakan di Kabupaten Tanah Bumbu berupa pengobatan kecacingan secara massal, namun masih belum bisa memenuhi indikator dalam pencapaian target berupa penurunan prevalensi cacingan sampai dengan di bawah $10 \%$ di setiap daerah kabupaten/kota.

Masih cukup tingginya prevalensi kecacingan walaupun telah dilaksanakan pengobatan dapat disebabkan adanya intensitas penularan yang tinggi dari lingkungan sekitar dan didukung oleh faktor risiko dari perilaku kebersihan pribadi (personal hygiene) yang kurang baik. $^{5}$ Perilaku higiene pribadi adalah suatu tindakan untuk memelihara kebersihan dan kesehatan seseorang untuk kesejahteraan baik fisik maupun psikisnya. Macam-macam higiene perorangan yaitu kebersihan kulit, kaki, tangan, kuku, perawatan rambut, perawatan rongga mulut dan gigi, perawatan mata, telinga dan hidung. ${ }^{6}$ Salah satu tujuan dari perawatan higiene perorangan adalah meningkatkan derajat kesehatan dan pencegahan terhadap penularan penyakit. Perilaku menjaga kebersihan diri yang baik dapat mengurangi risiko tertular infeksi penyakit termasuk kecacingan pada daerah dengan faktor sanitasi lingkungan yang kurang baik.

Keberhasilan program penanggulangan kecacingan tidak bisa ditekankan hanya pada upaya pengobatan saja, namun harus juga memperhatikan dalam upaya pencegahan penularan. Salah satunya adalah dengan cara menanamkan kebiasaan untuk menjaga kebersihan diri. Anak usia sekolah dasar merupakan usia paling rentan tertular kecacingan, di sisi lain pada usia ini juga merupakan masa yang paling baik untuk menanamkan suatu kebiasaan baik dalam menjaga kebersihan pribadi. Penelitian ini bertujuan untuk mengetahui persentase kecacingan pada murid SDN Muara Pagatan Ujung serta mengidentifikasi faktor-faktor perilaku anak dalam menjaga kebersihan pribadi yang 
diduga berisiko terhadap penularan kecacingan.

\section{METODE}

Penelitian dilaksanakan pada bulan Desember 2016 dengan disain studi potong lintang. Sampling feses dan wawancara kuesioner adalah total populasi yaitu murid kelas I sampai kelas VI SDN Muara Pagatan Ujung. Kriteria inklusi sampel adalah siswa SDN Muara Pagatan Ujung yang bersedia menyerahkan feses dan diwawancarai, kriteria eksklusi adalah siswa yang sakit pada saat pengambilan sampel. Pembagian pot feses didahului dengan penyuluhan singkat mengenai kecacingan dan cara memasukkan feses ke dalam pot. Inform consent disertakan untuk mendapat persetujuan dari orang tua atau wali murid. Pengambilan pot dilakukan dua hari berturut-turut setelah pembagian pot. Murid yang menyerahkan sampel feses kemudian diwawancara sesuai isi kuesioner. Pemeriksaan telur cacing pada feses dilakukan di Laboratorium Parasitologi Balai Litbangkes Tanah Bumbu dengan metode pemeriksaan langsung. Data disajikan secara deskriptif berupa hasil pemeriksaan feses dan tingkat perilaku higiene pribadi murid sesuai hasil wawancara.

\section{HASIL}

Total jumlah murid yang menyerahkan sampel feses dan diwawancarai sebanyak 100 orang. Berdasarkan hasil pemeriksaan diketahui sebanyak 13 anak (13\%) positif terinfeksi cacing. Hasil pemeriksaan dan karakteristik responden dapat dilihat pada Tabel 1.

Tabel 1. Karakteristik responden dan hasil pemeriksaan kecacingan pada murid SDN Muara Pagatan Ujung, Kecamatan Kusan Hilir Kabupaten Tanah Bumbu

\begin{tabular}{lcccc}
\hline \multirow{2}{*}{ Kategori } & \multicolumn{4}{c}{ Hasil pemeriksaan $(\mathrm{n}=100)$} \\
\cline { 2 - 5 } & Positif & $\%$ & Negatif & $\%$ \\
\hline Jenis kelamin & & & 43 & 49,43 \\
Laki-laki & 6 & 46,15 & 44 & 50,57 \\
Perempuan & 7 & 53,85 & & \\
Kelompok umur & 7 & & 48 & 55,17 \\
$6-9$ & 3 & 53,85 & 27 & 31,03 \\
$10-12$ & 3 & 23,08 & 12 & 13,79 \\
$12>$ & 23,08 & & \\
\hline
\end{tabular}

Bentuk infeksi berupa infeksi tunggal dan infeksi campuran. Jenis cacing yang ditemukan adalahTrichuris trichiura (cacing cambuk), Ascaris lumbricoides (cacing gelang) dan Hymenolepis sp. (cacing pita kerdil). Rincian jenis dan persentase infeksi yang ditemukan pada anak-anak di SDN Muara Pagatan Ujung dapat dilihat pada Tabel 2.

Tabel 2. Jenis cacing yang menginfeksi murid SDN Muara Pagatan Ujung, Kecamatan Kusan Hilir Kabupaten Tanah Bumbu

\begin{tabular}{lcc}
\hline \multicolumn{1}{c}{ Jenis cacing } & Frekuensi $(\mathrm{n}=13)$ & $(\%)$ \\
\hline Trichuris trichiura & 7 & 53,85 \\
Ascaris lumbricoides & 1 & 7,69 \\
Hymenolepis sp. & 3 & 23,08 \\
Trichuris trichiura + Ascaris lumbricoides & 1 & 7,69 \\
Trichuris trichiura + Hymenolepis sp. & 1 & 7,69 \\
\hline
\end{tabular}




\section{Perilaku personal hygiene siswa SDN Muara Pagatan Ujung yang berhubungan dengan risiko infeksi kecacingan}

\begin{abstract}
Tidak/kadang-kadang mencuci tangan pakai sabun sebelum makan Tidak/kadang-kadang mencuci tangan dan kaki pakai sabun setelah bermain di tanah

Tidak/kadang-kadang mencuci tangan pakai sabun setelah BAB

Tidak/kadang-kadang menggunakan alas kaki setiap keluar rumah

Punya kebiasaan menghisap jari tangan

Punya kebiasaan menggigit kuku jari

Suka makan sayur mentah
\end{abstract}

0

Berisiko

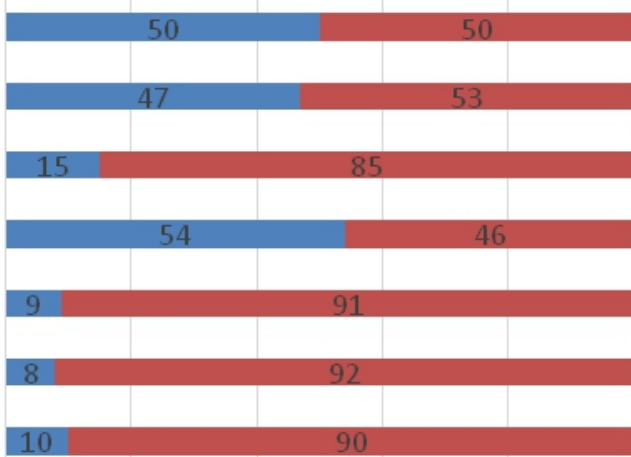

$\begin{array}{lllll}20 & 40 & 60 & 80 & 100\end{array}$

120

Gambar 1. Perilaku perilaku higiene pribadi murid SDN Muara Pagatan Ujung, Kecamatan Kusan Hilir Kabupaten Tanah Bumbu.

Hasil wawancara yang dilakukan pada 100 orang siswa, masih terdapat beberapa perilaku higiene pribadi yang berkaitan dengan risiko kemungkinan terinfeksi cacing. Walaupun tidak memiliki hubungan yang signifikan terhadap kejadian kecacingan, beberapa jenis perilaku masih sebagian besar tidak dilakukan atau hanya kadang-kadang dilakukan seperti: perilaku mencuci tangan pakai sabun sebelum makan $(50 \%)$, perilaku mencuci tangan dan kaki pakai sabun setelah bermain di tanah $(47 \%)$ dan perilaku penggunaan alas kaki setiap keluar rumah (54\%). Tabel perilaku higiene pribadi dan kejadian kecacingan pada siswa dapat dilihat pada tabel 3 .

Tabel 3. Perilaku higiene pribadi dan kejadian kecacingan pada murid

SDN Muara Pagatan Ujung, Kecamatan Kusan Hilir Kabupaten Tanah Bumbu

\begin{tabular}{|c|c|c|c|c|}
\hline \multirow[t]{2}{*}{ Perilaku berisiko terhadap kecacingan } & \multicolumn{2}{|c|}{$\begin{array}{c}\text { Hasil } \\
\text { pemeriksaan } \\
\text { kecacingan }\end{array}$} & \multirow[t]{2}{*}{$\mathrm{N}(\%)$} & \multirow[t]{2}{*}{$p$-value } \\
\hline & Pos & Neg & & \\
\hline Tidak/kadang-kadang mencuci tangan pakai sabun sebelum makan & 5 & 45 & $50(50,00)$ & 0,372 \\
\hline $\begin{array}{l}\text { Tidak/kadang-kadang mencuci tangan dan kaki pakai sabun } \\
\text { setelah bermain di tanah }\end{array}$ & 5 & 42 & $47(47,00)$ & 0,508 \\
\hline Tidak/kadang-kadang mencuci tangan pakai sabun setelah BAB & 2 & 13 & $15(15,00)$ & 0,967 \\
\hline Tidak/kadang-kadang menggunakan alas kaki setiap keluar rumah & 8 & 46 & $54(54,00)$ & 0,559 \\
\hline Punya kebiasaan menghisap jari tangan & 3 & 6 & $9(09,00)$ & 0,057 \\
\hline Punya kebiasaan menggigit kuku jari & 1 & 7 & $8(08,00)$ & 0,965 \\
\hline Suka makan sayur mentah & 1 & 9 & $10(10,00)$ & 0,766 \\
\hline
\end{tabular}




\section{BAHASAN}

Berdasarkan Peraturan Menteri Kesehatan Republik Indonesia Nomor 15 tahun 2017 tentang penanggulangan cacingan, ${ }^{7}$ klasifikasi prevalensi dari hasil penelitian didapatkan prevalensi kecacingan sudah cukup rendah yaitu sebesar $13 \%$. Namun hasil ini perlu menjadi perhatian karena survei dilakukan pada bulan Desember 2016 yang hanya berselang 3 bulan sesudah dilakukannya pemberian obat kecacingan di sekolah tersebut (menurut informasi dari pihak sekolah). Setelah meminum obat cacing maka seluruh cacing yang ada di dalam tubuh akan mati. Cacing tidak bereproduksi dalam inang manusia, cacing yang ada dalam tubuh manusia adalah akibat dari infeksi dari luar. ${ }^{8}$ Beberapa anak ditemukan positif kecacingan, padahal 3 bulan sebelumnya anak tersebut telah meminum obat cacing yang diberikan di sekolah, hal ini mengindikasikan terjadinya siklus penularan yang relatif cepat pada anak-anak di wilayah tersebut. Infeksi cacing dapat terjadi secara langsung maupun tidak langsung melalui sumber sekunder seperti makanan, air, sayuran dan buah-buahan karena kebanyakan infeksi soil transmitted helminth (STH) diperoleh melalui rute faecaloral. ${ }^{9}$ Infeksi umumnya lebih sering terjadi di daerah-daerah, yang kebersihan dan sanitasinya rendah. ${ }^{10}$

Cacingan pada dasarnya dapat menginfeksi anak-anak dari semua jenis kelamin. ${ }^{11}$ Beberapa penelitian di Indonesia maupun di luar negeri menyatakan bahwa tidak terdapat hubungan antara jenis kelamin dengan infeksi cacing. ${ }^{12,13}$ Pada kasus ini murid perempuan lebih banyak menderita kecacingan dibandingkan laki-laki. Survei yang dilakukan di wilayah lain di Kabupaten Tanah Bumbu maupun daerah lain di Indonesia juga menunjukkan proporsi hasil yang sama. ${ }^{11,14,15}$ Secara teori peluang kejadian cacingan lebih banyak ditemukan pada anak laki-laki karena aktifitas bermainnya lebih banyak di luar rumah dan berinteraksi dengan media tanah dan bekerja di kebun, namun kenyataannya hasil observasi anak laki-laki dan perempuan hampir memiliki kebiasaan bermain yang sama. Walaupun jenis permainan berbeda namun aktiftas anak perempuan lebih banyak dilakukan di tanah. ${ }^{16}$
Murid yang menderita kecacingan lebih dominan pada usia dibawah 10 tahun. Beberapa hasil penelitian kelompok umur 9-10 tahun paling banyak terinfeksi cacingan dan terdapat hubungan yang signifikan antara usia anak dengan kejadian infeksi cacing. . $^{6,17,18}$

Jenis cacing yang menginfeksi
merupakan STH kecuali cacing
Hymenolepis sp., artinya sebagian besar cacing tersebut ditularkan melalui media tanah. Jenis cacing Trichuris trichiura atau cacing cambuk paling banyak ditemukan. Hasil survei yang dilakukan di wilayah lain di Kabupaten Tanah Bumbu juga mendapatkan jenis cacing $T$. trichiura yang mendominasi dari seluruh jenis cacing yang ditemukan.4,11,19 Berbeda dengan cacing STH, Hymenolepis sp. tidak memerlukan media tanah dalam penularannya. Infeksi kebanyakan terjadi secara langsung dari tangan ke mulut, hal ini sering terjadi terutama pada anak-anak. Cacing ini termasuk jenis cacing pita pendek, yang daur hidupnya tidak mempunyai hospes perantara. Hospesnya adalah manusia dan tikus, cacing ini menyebabkan penyakit himenolepiasis. ${ }^{20}$

Faktor-faktor yang berhubungan dengan infeksi cacing pada anak erat hubungannya dengan higiene dan sanitasi, faktor tersebut diantaranya meliputi kebersihan kuku, penggunaan alas kaki, kebiasaan bermain di tanah dan kebiasaan mencuci tangan. ${ }^{21}$ Penelitian yang dilakukan oleh Jaya, et al menunjukkan bahwa tingkat perilaku higiene pribadi sangat berpengaruh terhadap status kecacingan. ${ }^{5}$

Berdasarkan hasil wawancara diketahui bahwa masih ada beberapa faktor perilaku higiene pribadi yang dapat meningkatkan risiko terinfeksi cacing pada anak-anak. Sebanyak 54\% murid mengaku tidak atau kadang-kadang saja memakai alas kaki setiap keluar rumah. Beberapa penelitian menunjukkan bahwa penggunaan alas kaki berkaitan erat terhadap kejadian kecacingan sehingga menjadi faktor risiko. ${ }^{15}$ Saat berangkat ke sekolah semua murid memang memakai sepatu, namun berdasarkan pengakuan saat diwawancara sebagian mereka 
merasa tidak nyaman memakai alas kaki saat bermain di luar ruangan. Kebiasaan tidak memakai alas kaki dari sebagian murid ini biasanya akan ditiru oleh teman-temannya yang lain sehingga semakin banyak anak yang tidak memakai alas kaki saat bermain di luar ruangan karena anak-anak pada umumnya sangat mudah terpengaruh pada lingkungan sekitarnya, termasuk meniru perilaku orang-orang di sekitar. ${ }^{22}$

Sebagian besar anak yang tidak memakai alas kaki saat bermain mengaku tidak atau hanya kadang kadang mencuci tangan dan kaki setelah bermain (47\%) dan $50 \%$ tidak atau hanya kadang-kadang mencuci tangan sebelum makan. Beberapa penelitian menyatakan bahwa kebiasaaan mencuci tangan/kaki mempunyai hubungan dengan kejadian kecacingan. ${ }^{6,23}$ Murid yang tidak mempunyai kebiasaan mencuci tangan dapat terkena kecacingan 5 kali lebih besar dibandingkan murid yang mempunyai kebiasaan mencuci tangan. ${ }^{21}$ Telur cacing infektif akan terbawa bersama tangan atau kaki murid yang kebetulan beraktivitas di tanah yang terdapat telur tersebut, selanjutnya telur akan tertelan jika tangan yang belum dicuci digunakan untuk makan.

Masih banyaknya anak yang belum memiliki perilaku hidup bersih dikhawatirkan akan menambah risiko tertular penyakit terutama kecacingan. Penanaman dan penerapan perilaku hidup bersih sangat perlu dilakukan sejak dini agar risiko tertular penyakit kecacingan terutama pada kelompok usia yang rentan dapat dicegah.

\section{KESIMPULAN}

Berdasarkan penelitian ini dapat disimpulkan bahwa prevalensi kecacingan pada murid SDN Muara Pagatan Ujung terlihat rendah. Sebagian besar infeksi disebabkan oleh cacing STH. yang mungkin disebabkan murid masih banyak berperilaku kurang higienis yaitu tidak mengenakan alas kaki saat bermain di luar, tidak mencuci tangan dan kaki sehabis bermain di luar dan tidak mencuci tangan sebelum makan.

\section{SARAN}

Pengobatan secara selektif perlu dilakukan pada murid yang terinfeksi cacing. Diperlukan edukasi pada murid mengenai pentingnya menjaga kebersihan pribad terutama dalam hal kebiasaan menggunakan alas kaki serta kebiasaan mencuci tangan dan kaki sehabis bermain dan sebelum makan. Edukasi perlu diiringi dengan pengadaan fasilitas pendukung kebersihan di sekolah seperti tempat cuci tangan dengan sabun dan adanya peraturan yang mengharuskan siswa untuk selalu memakai alas kaki.

\section{KONTRIBUSI PENULIS}

Kontribusi penulis pada artikel ini yaitu $\mathrm{BH}$ sebagai kontributor utama bertanggungjawab dalam ide, konsep dan pembuatan seluruh bagian artikel. A sebagai kontributor anggota bertanggungjawab dalam pengumpulan dan analisis data. EH sebagai kontributor anggota bertanggungjawab dalam pengumpulan data. DA sebagai kontributor anggota bertanggungjawab dalam analisis hasil dan pembahasan. $J$ sebagai kontributor anggota bertanggungjawab dalam pengumpulan dan analisis data serta penelusuran sumber acuan.

\section{UCAPAN TERIMA KASIH}

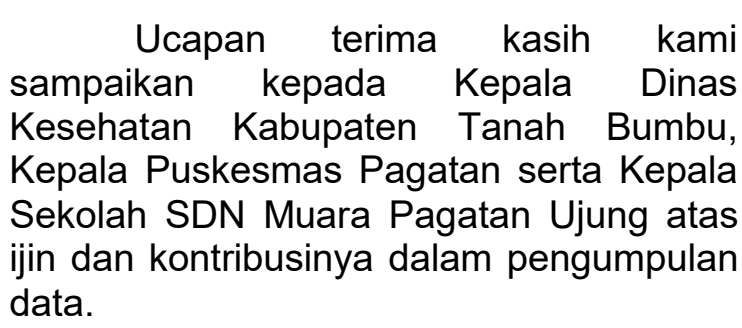

\section{DAFTAR PUSTAKA}

1. Blair P, Diemert D. Update on Prevention and Treatment of Intestinal Helminth Infections. Curr Infect Dis Rep. 2015;17(12).

2. Indriyati L, Waris L, Luciasari E. Kerugian Finansial Akibat Kecacingan: Studi di Kabupaten Nunukan. Penel Gizi Makan. 2014;37(2):155-60.

3. World Health Organization. Soiltransmitted helminth infections [Internet]. 2019. Available from: https://www.who.int/news-room/factsheets/detail/soil-transmitted- 
helminth-infections

4. Paisal, Hairani B, Hariyati E, Indriyati L. Dampak tingginya prevalensi Trichuris trichiura terhadap kebijakan pengobatan massal kecacingan di tiga SD di Kabupaten Tanah Bumbu. J Kebijak Pembang. 2017;12(1):77-83.

5. Jaya IKS, Romadilah. Hubungan infeksi kecacingan dan perilaku higiene pribadi dengan kadar hemoglobin $(\mathrm{Hb})$ Siswa SDN 51 Cakranegara Kota Mataram Tahun 2013. Media Bina IIm. 2013;7(19783787):42-5.

6. Martila M, Sandy S, Paembonan N. Hubungan Higiene Perorangan dengan Kejadian Kecacingan pada Murid SD Negeri Abe Pantai Jayapura. J Plasma. 2017;1(2):87-96.

7. Kementerian Kesehatan Republik Indonesia. Peraturan Menteri Kesehatan Republik Indonesia nomor 15 tahun 2017 tentang penanggulangan cacingan. 2017 p. 78.

8. Ziegelbauer K, Speich B, Mäusezahl D, Bos R, Keiser J, Utzinger J. Effect of sanitation on soil-transmitted helminth infection: Systematic review and metaanalysis. PLoS Med. 2012;9(1).

9. Ojurongbe $\mathrm{O}$, Oyesiji $\mathrm{K}$, Ojo $\mathrm{J}$, Odewale G, Adefioye O, Olowe A, et al. Soil transmitted helminth infections among primary school children in IleIfe Southwest , Nigeria: A crosssectional study. Int Res J Med Med Sci. 2014;2(1):6-10.

10. Salim N, Schindler T, Abdul U, Rothen $J$, Genton B, Lweno O, et al. Enterobiasis and strongyloidiasis and associated co-infections and morbidity markers in infants, preschool- and school-aged children from rural coastal Tanzania: A cross-sectional study. BMC Infect Dis. 2014;14(1):1-17.

11. Juhairiyah; Hairani, B Indriyati L. Prevalensi Infeksi Cacing pada Murid Sekolah Dasar Negeri 1 Harapan Maju Kecamatan Karang Bintang Kabupaten Tanah Bumbu. Spirakel. 2017;9(1):2733.

12. Faridan K, Malinae L, Audhah N Al.
Faktor-faktor yang berhubungan dengan kejadian kecacingan pada siswa Sekolah Dasar Negeri Cempaka 1 Kota Banjarbaru. J Buski. 2013;4(3):121-7.

13. Ahmed A, Al-Mekhlafi HM, Choy SH Ithoi I, Al-Adhroey $\mathrm{AH}$, Abdulsalam AM, et al. The burden of moderateto-heavy soil-transmitted helminth infections among rural malaysian aborigines: An urgent need for an integrated control programme. Parasites and Vectors. 2011;4(1):242.

14. Chadijah et al. Kejadian penyakit cacing usus di Kota Palu dan Kabupaten Donggala, Sulawesi Tengah. Buski. 2013;4(4):181-7.

15. Semuel Sandy, Sri Sumarni S. Analisis Model Faktor Risiko Yang Mempengaruhi Infeksi Kecacingan Yang Ditularkan Melalui Tanah Pada Siswa Sekolah Dasar Di Distrik Arso Kabupaten Keerom, Papua. Media Penelit dan Pengemb Kesehat. 2015;25(1):1-14.

16. Sandy S, Sumarni S, Soeyoko. Analisis model faktor risiko yang mempengaruhi infeksi kecacingan yang ditularkan melalui tanah pada siswa sekolah dasar di Distrik Arso Kabupaten Keerom, Papua. Media Litbangkes. 2015;25(1):1-14.

17. Darlan DM, Kaban FFV. Correlation between soil transmitted helminth infection and incidence of anemia at public primary school 060925. Int J PharmTech Res. 2016;9(6):185-90.

18. Darlan DM, Tala ZZ, Amanta C, Warli SM, Arrasyid NK. Correlation between Intestinal Parasite Infection and Eosinophil Levels among Primary School Children in Medan. Open Access Maced J Med Sci. 2017;5(2):142-6.

19. Hairani B, Hidayat S, Indriyati L. Helminth Infection in Primary School Children and Characteristics of Settlement in The Coastal Village of Kusan Hilir Subdistrict Tanah Bumbu District, South Kalimantan Province , Indonesia. Int J Eng 
Technol Sci. 2018;5(3):66-72.

20. Bisara D, Mardiana. Kasus Kecacingan pada Murid Sekolah Dasar di Kecamatan Mantewe, Kabupaten Tanah Bumbu Kalimantan Selatan Tahun 2010. J Ekol Kesehat. 2014;13(3):255-64.

21. Kartini S. Kejadian kecacingan pada siswa sekolah dasar negeri kecamatan rumbai pesisir pekanbaru the helminthiasis on the state elementary school dtudent on kecamatan Rumbai Pesisir Pekanbaru. 2016;3(2):53-8.

22. Permono H. Peran Orangtua Dalam Optimalisasi Tumbuh Kembang Anak Untuk Membangun Karakter Anak Usia Dini. In: Prosiding Seminar Nasional Parenting 2013. Jakarta; 2013. p. 3447.

23. Mutoharoh S. Perilaku Mencuci Tangan dan Kejasian Kecacingan pada Siswa SEkolah Dasar di Kecamatan Pertanahan Kabupaten Kebumen. J IIm Kesehat Keperawatan. 2015;11(2). 